\title{
LAND USE PLANNING IN HYDROPOWER DEVELOPMENT A CASE STUDY OF UPPER TAMAKOSHI HYDROELECTRIC PROJECT
}

\author{
Subash Ghimire \\ Assistant Professor, Department of Civil and Geomatics Engineering, Kathmandu University, \\ Dhulikhel, Nepal \\ Corresponding address: subash_ghimire@ku.edu.np \\ Received 21 August, 2011; Revised 28 December, 2011
}

\begin{abstract}
Many developing countries do not focus on land use planning in hydropower development. As a result hydropower projects are not sustainable. The aim of the study is to analyze the cause and effects of land use planning in hydropower development. The primary and secondary data were collected in a case study site at the Upper Tamakoshi Hydroelectric Project (UTHEP) in Dolakha district of Nepal. Household questionnaire, key informants' interviews and field observation were conducted to collect primary data while the relevant documents such as detailed feasibility report, property valuation report and spatial data (cadastral data, image etc.) were also collected for the study. The primary and secondary data reveals that Land use changes involved in the UTHEP implementation is basically due to the permanent and temporary land acquisition for project structures, facilities and reservoir area. The total land acquired for various project components like access road, powerhouse, desanding basin, reservoir as well as construction borrow pits and quarries, temporary and permanent work camps and construction of access road is estimated to be 182 ha. The secondary data reveals that 66 ha are allocated in agricultural land, 78 ha in forest land and 38 ha in the barren and cliff land. The results from secondary data and interviews confirm that UTHEP has planned to distribute $10 \%$ share to the residents of Dolakha district to promote local level investment. Finally, the study finds that land use planning has very important role for minimizing negative social and environmental effects thus create sustainability of the hydropower projects. It is also found that overall environmental impacts are limited because of technological development such as tunnel and underground powerhouse in UTHEP. The land tenure, Land use planning stakeholders and their role, Governance, policy, social structure etc. are the basic requirements of land use planning for sustainable development of hydropower projects.
\end{abstract}

Key words: Land use planning, hydroelectric project, land acquisition

\section{INTRODUCTION}

Investment in hydropower development which requires a large quantity of land is very important for the development of any country. As land can neither be decreased nor increased, it should be effectively and efficiently use in a sustainable way [1]. A component of hydropower projects occupies various types of land during its development. Many developing countries do not consider the land use planning in hydropower development. Land use plan is not prepared in Nu river hydropower development in China. Many of the proposed dam is situated in UNESCO world heritage site and in the conservation area. Nu river project affects number of distinct ethnic groups who maintain their religious and cultural tradition. Resettlement is not possible on this ethnic group because of integration into population of various customs, languages and agricultural tradition [2]. Because of lack of access to information and transparency in planning processes [3], $\mathrm{Nu}$ river project faces obstacles in its development. Similarly, in Nepal, land use planning has not considered in hydropower development plan. Transparency in information dissemination, decision making, involvement of key stakeholders on key issues and time bound solution can hardly be found 
during hydropower development [4]. Therefore, hydropower projects are not sustainable. While in Norway according to [5], land use planning is well considered in Aurland hydropower development project. The various ways to minimize negative effect of construction on the cultural and natural landscape were considered in its development. These measures include extensive use of tunnels in road construction and re-vegetation of the disposal site and quarries. Because of technical development such as tunneling and underground constructions, the environmental impacts were also limited. Aesthetic aspect of the project area is maintained from this technical development because large part of the installations is not visible and results no impacts on the surroundings above earth.

Land use as one of the key components of Land Administration plays very important role for the sustainability of the environment and hydropower projects itself. In this context, Land use planning plays very important role for the sustainability of hydropower projects. Land use planning is strongly related to private property rights. Imposing a certain land use to private owners will interferes in the characteristics of the private property rights, also called the 'bundle of rights 'that constitute a private property right. Land use planning ('Physical planning') is the process of allocating resources, particularly land, in order to achieve maximum efficiency while respecting the nature of the environment and the welfare of community [6]. According to [7], the hydropower project could be a boulevard for sustainable development if it is developed with good planning.

Many countries look upon hydropower as a key to their future economic development. Hydropower consisting of major components like dam, intake, canal, desander basin, fore bay, penstock, powerhouse, tail race, transmission line etc. is the main source of electrical energy of Nepal. Nepal is one of the Himalayan countries with a high power potential. It has theoretically hydropower potential of $83,000 \mathrm{Mw}$ and economical potential of 43,000 Mw. At present, the installed capacity of hydropower is less than $1000 \mathrm{Mw}$, less than $2 \%$ of the total economically feasible potential [8].

According to [9] "By examining all uses of land in an integrated manner, it makes it possible to minimize the conflicts, to make most efficient trade-offs and to link social and economic development with environmental protection and enhancement, thus helping to achieve the objectives of sustainable development. On this background, there is an urgent need for the country to develop a sustainable path for the generation of energy which has direct relations on Land use planning to benefit the country.

The aim of the study is to analyze the cause and effects of land use planning in hydropower development. The specific objectives of the study are to highlight the land use pattern in UTHEP and to find out the land use planning requirements in the process of hydropower development.

\section{STUDY AREA}

The Upper Tamakoshi Hydroelectric Project (UTHEP) is the study area. It is located in Eastern part of Nepal and has an installed capacity of 456 MW. It is developing by Upper Tamakoshi Hydroelectric project in Nepal, subsidiary body of Nepal Electricity Authority. It is the largest hydroelectric project in Nepal to date and highly attractive and low cost project. Amongst other hydroelectricity project in Nepal, Tamakoshi is the cheapest based on unit electricity product. It seems more beneficial environmentally and economically. The origin 
of Tamakoshi is from the glaciers. Therefore, it maintains the constant flow of water every month. The major developers are the Nepalese themselves; NEA, Employment provident fund, Citizen Investment Trust, Rastriya Beema Santhasan etc [10, 11].

The project is located in Dolakha district, Janakpur zone in central development region of Nepal (Fig. 1). It is located in the range of Himalayas, southern part of Lamabagar VDC, in Dolakha district. The project site is located in $86^{\circ} 12^{\prime}$ '00'easting and $27^{\circ} 55^{\prime}$ ' $00^{\prime \prime}$ northing at an elevation of $4085 \mathrm{~m}$. The dam site is at Lamabagar village, $100 \mathrm{~km}$ far from the Kathmandu, $8 \mathrm{~km}$ south of China border and $30 \mathrm{~km}$ north of district headquarter, Charikot. The project area is enclosed by longitudes from $86^{\circ} 10^{\prime} 00^{\prime \prime}$ to $86^{\circ} 16^{\prime} 00^{\prime \prime}$ and latitude from $27^{\circ} 49^{\prime} 00^{\prime \prime}$ to $27^{\circ} 58^{\prime} 00$.

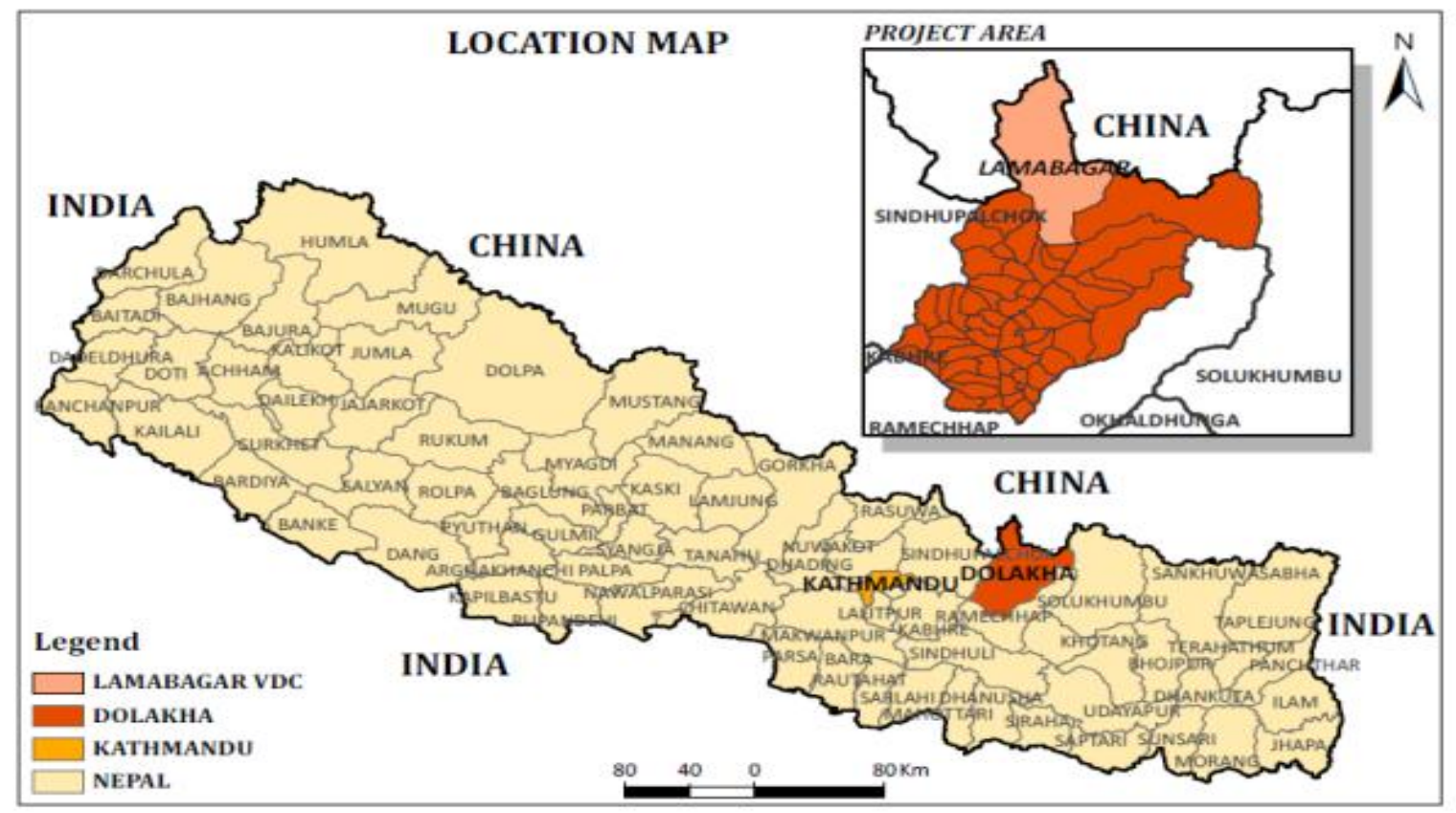

Figure 1 Location map of UTHEP

\section{MATERIALS AND METHODS}

The desk study is followed by the literature review. Scientific literature such as journal articles, conference papers, books and documents including research/project reports are used for the purpose of the study. The primary and secondary data were collected in a case study site at the Upper Tamakoshi Hydroelectric Project (UTHEP) in Dolakha district of Nepal. Household questionnaire, key informants' interviews and field observation were conducted to collect primary data while the relevant documents such as detailed feasibility report, property valuation report and spatial data such as images were also collected for the study. A field visit was performed from 10th September 2010 to 10th October 2010 to field study site in Dolakha, Nepal. Important personalities from Upper Tamakoshi Hydroelectric Project Limited (UTHEPL), experts/ academia, civil society members, Village development committee (VDC) heads and some affected families of the project area were contacted for interviewing and household questionnaire survey. 


\section{DATA ANALYSIS}

The secondary data confirm that the major project features of UTHEP include dam, desander (desilting basin), headrace tunnel, penstock tunnel, powerhouse, tailrace tunnel and transmission line. This section is discussed in the following subsections.

\section{Special feature of the project}

The special features of UTHEP component are as follows:

Access road: new construction- $28.65 \mathrm{~km}$, upgrading- $33.0 \mathrm{~km}$

Diversion structure: dam height-15 m from river bed, length-60 m

Settling basin: number of units- 2, length and breadth- $246 \mathrm{~m} * 26 \mathrm{~m}$, particle size to be settled- $0.15 \mathrm{~mm}$

Reservoir: surface area covered- 21.3 ha, live storage- $790000 \mathrm{~m}^{3}$

Headrace tunnel: shape of tunnel- horse-shoe shape, diameter-5.82 m, length $-7170 \mathrm{~m}$

Powerhouse: type underground, floor area $-112 \mathrm{~m} * 12.9 \mathrm{~m}$, power house height $-29 \mathrm{~m}$

Turbine: number of units -4 , design discharge $-4 * 11 \mathrm{~m}^{3} / \mathrm{sec}$.

Tailrace tunnel: length- $2500 \mathrm{~m}$

Power: design gross head $-820 \mathrm{~m}$, design net head $-806 \mathrm{~m}$

The detail layout of UTHEP and settlements in the project area is shown in the Figure 2.

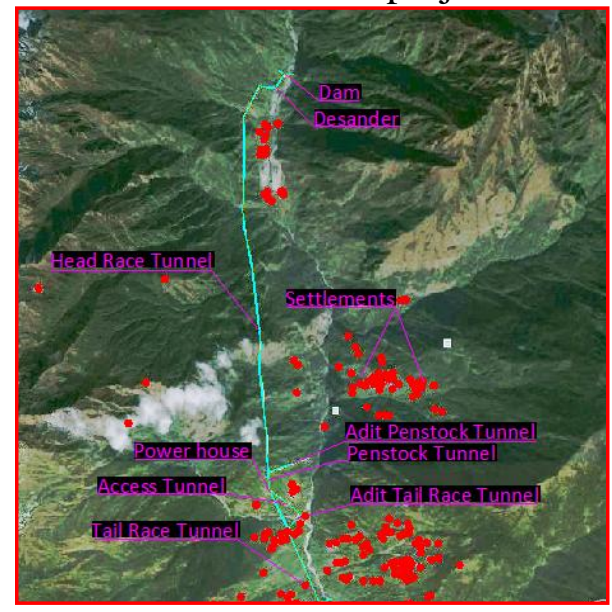

Figure 2 Layout of UTHEP

It is found that settlements in the headwork area are very few comparing to powerhouse and tailrace tunnel area (Figure 2). Based on feasibility study report of UTHEP, UTHEP is allocated in private land and state land (government and public land). Although there are two Buddhist Gumbas in Lamabagar, the hydropower project does not have major effects on these religious lands. The private land has various categories - Khet, Bari, Kharbari and others on the basis of productivity of crops. The government land used by the project is ditches, bushy land and forestland. The forestland is covered by tropical and subtropical flora and is managed by community forest user groups.

\section{Land allocated for the project}

The land used by various components of the project is tabulated in Table 1.

Table 1. Land allocated for the project 


\begin{tabular}{|l|l|l|l|l|}
\hline \multirow{2}{*}{ Project Component } & \multicolumn{3}{c|}{ Land Types } & \multicolumn{1}{c|}{$\begin{array}{l}\text { Total Land } \\
\text { Allocated }\end{array}$} \\
\cline { 2 - 5 } & $\begin{array}{l}\text { Agriculture } \\
\text { land }\end{array}$ & $\begin{array}{l}\text { Forest } \\
\text { Land }\end{array}$ & $\begin{array}{l}\text { Cliff/Barren } \\
\text { Land }\end{array}$ & \\
\hline $\begin{array}{l}\text { Headwork (reservoir, Intake, } \\
\text { Desander) and powerhouse+ Adit }\end{array}$ & 17 & 33 & 5 & 55 \\
\hline Quarry Area & - & 1 & 4 & 5 \\
\hline Camps & 10 & 6 & 3 & 19 \\
\hline Spoil & 10 & 2 & 4 & 16 \\
\hline Access Road & 29 & 36 & 22 & 87 \\
\hline Total & 66 & 78 & 38 & 182 \\
\hline
\end{tabular}

Based on key informants interviews it is found that the change in land use pattern mostly occurs along the road corridor in 9 VDCs. The project affected area covers ten VDCs and one municipality. Among the affected VDCs/municipality, four VDCs and the municipality namely: Suspachhemawati, Sundrawati, Sunkhani and Orang VDCs and Bhimeshwar municipality are affected by upgrading of the existing district road. The new access road is constructed in Gaurishankar, Khare, Laduk Lamidanda and Bulung VDCs and the entire project structures are constructed in Lamabagar VDC. The details of private land such as Khet, Bari and Kharbari allocated for various component of UTHEP based on the feasibility report are shown in Table 2.

Table 2. Classification of affected land by different components of the project

\begin{tabular}{|l|c|c|c|c|c|c|}
\hline \multirow{2}{*}{ Project Sites } & \multicolumn{6}{|c|}{ Affected Land (ha) } \\
\cline { 2 - 7 } & Khet & Bari & Kharbari & others & Total & Percentage \\
\hline Head works & 0 & 9 & 0 & 0 & 9 & 20 \\
\hline Camp Site & 1 & 3 & 1 & 0 & 5 & 11 \\
\hline Access Road & 4 & 24 & 1 & 0 & 29 & 64 \\
\hline Power House & - & 2 & - & - & 2 & 5 \\
\hline Spoil Bank & - & - & - & - & - & - \\
\hline Total & 5 & 38 & 2 & 0 & 45 & 100 \\
\hline
\end{tabular}

Based on the field observation, it is found that land use changes involved in the UTHEP implementation is basically due to the permanent and temporary land acquisition for project structures, facilities and reservoir area. The secondary data indicates that a total of 54 ha of land under different land use will be permanently converted to project features, whereas 19 
ha of land will be used for temporary and permanent camps during the construction period. The total land take for the access road is 87 ha. Based on the key informants interviews and field observation it is found that Land use changes will mostly occur along the access road and in Lamabagar VDC where the project structures are located. The change in land use pattern will mostly occur along the road corridor in 9 VDCs. The permanent land use change may result in permanent loss of production resource base particularly of the cultivated land, private forest and grassland.

The secondary data shows that total land acquired for various project components like access road, powerhouse, desanding basin, reservoir as well as construction borrow pits and quarries, temporary and permanent work camps and construction of access road is estimated to be $182 \mathrm{ha}$. The estimate of different types of land involved in land take is shown in Table 1. About $43 \%$ of the land acquired for the project will be forest area, $36 \%$ percent cultivated land, and the rest barren land and cliff. The impact can be classified as high and long-term impact.

As the land take for the project is considerably high, the permanent land take will bring about significant changes in land use of the area. No significant impact on topography and land use is expected during the operation phase. All temporary land acquired will be converted to its original use or agreed new uses towards the end of the construction period.

\section{Land acquiring process}

Most of the respondents of household questionnaire reply that land is acquired by the compulsory purchase in UTHEP. As there are several political, local and social problems regarding land acquisition in UTHEP, progress of access road construction is below expectation [12]. From the feasibility report, it is found that UTHEP forms the compensation fixing committee (CFC) which consists of the CDO, Chief District Land Administration and Revenue Office, Project chief or an officer designated by the CDO and the representative of the District Development Committee (DDC) to decide the amount of the compensation. Based on property valuation report, it is known that they compensate for damage of crops with the rate from district agricultural development office.

According to [13], from the past experiences of similar projects, the appropriate method of compensation in rural Nepal is the land-for-land compensation for the affected households. However, due to land scarcity and steep terrain, it is difficult to find agricultural land around Lamabagar area. Under these circumstances a fully-fledged relocation plan is not developed in this project. Therefore, the land-for-land compensation method encounters numerous hurdles in terms of general applicability in the project area. So, for this type of scenario, cash compensation is done in the project.

The secondary data reveals a total of 276 households are affected by the project. Out of 276 households, 14 families are relocated and the rest lose some or all of their land and property. Most of the project affected families (PAF's) are Tamangs and Gurungs, followed by other ethnic groups like Chhetries, Brahmin, Sherpa and Newar. Occupational castes like Kami, Damai, and Sharki also exists in the project area. According to GoN classification, there are approximately 10 indigenous ethnic groups in UTHEP area. Among them the majority groups are: Sherpa, Gurung, Newar, Thami, Jirel and occupational caste groups like Damai. Kami and Sarki. 15 pakki houses are acquired for the project and one school is relocated. The 
results from secondary data and interviews confirm that UTHEP has planned to distribute $10 \%$ share to the residents of Dolakha district to promote local level investment and to improve livelihood of the people.

\section{RESULTS AND DISCUSSION}

The Upper Tamakoshi Hydroelectric project has acquired the agricultural land, forestland and barren land to build the project. The price of the land is fixed by forming the compensation fixing committee, which is one of the positive indicators of this endeavor to minimize the conflicts.

The technological development such as underground and tunnel structures shows that this project has minimum impact on environment. As the land take for the project is considerably high, the permanent land take brings about significant changes in land use of the area. The impact is expected to be significant, and for a long duration. No significant impact on topography and land use is expected during the operation phase. All temporary land acquired will be converted to its original use or agreed new uses towards the end of the construction period. The $10 \%$ of share is distributed to residents of Dolakha district to make them owner of the project. It is the positive aspects in hydropower development in Nepal and minimize the land conflicts such as conflicts due to low valuation, low compensation etc. Access to information about the project is higher in municipality area and minimum to local people. Land is acquired by expropriation which causes more land conflicts such as conflicts created with low valuation and low compensation. These conflicts hinder the progress of the project. Because of the construction of Upper Tamakoshi Hydroelectric Project, land use pattern is changed from agricultural land to built up area having project features. It is found that land tenure, governance and social structure are one of the requirements in the land use planning for the sustainable hydropower development.

\section{CONCLUSION}

The study concludes that the permanent land use change results in permanent loss of production resource base particularly of the cultivated land, private forest and grassland. Land use planning has very important role for minimizing negative social and environmental effects thus create sustainability of the hydropower projects. It is also found that overall environmental impacts are limited because of technological development such as tunnel and underground powerhouse in UTHEP. The land tenure and its allocations, Land use planning stakeholders and their role; governance, land use policy, social structure etc. are the basic requirements of land use planning for sustainable development of hydropower projects.

\section{ACKNOWLEDGEMENTS}

The author would like to highly acknowledge Dr. Rijan Bhakta Kayastha and Dr. Dhurba Prasad Gauchan for their constructive comments and valuable suggestions in the manuscript. Likewise, the author is greatly thankful to the Upper Tamakoshi Hydroelectric Project Limited for providing necessary documents. The author is also thankful to Kathmandu University and University of Twente, Faculty of Geo Information Science and Earth Observation, ITC, The Netherlands for their support to carry out the study. 


\section{REFERENCES}

[1] Oluwamotemi, D K, Land Acquisition, Compensation And Resettlement In Developing Economies: Nigeria As A Case Study. TS IE - Environment and Energy, Policy and Practice, 2010.

[2] Brown, P. H., Magee, D., \& Xu, Y. Socioeconomic vulnerability in China's hydropower development. [DOI:10.1016/j.chieco.2008.06.002] China Economic Review, 19(4)(2008) 614.

[3] Yardley, J, Dam Building Threatens China's 'Grand Canyon'. New York Times, March 10, 2004.

[4] Shah, S, Hydropower development in Nepal-Current situation and private sector, presented on May 19th, 2008.

[5] VIII, I H i a A, Hydropower Good Practices:Environment Mitigation Measures and Benefits : case study 10-04: Landscape and cultural Heritage- Aurland Hydropower Development, Norway,2006.

[6] UN/ECE, Land Administration Guidelines With Special Reference to Countries in Transition, 50, 1996.

[7] Maskey, R K, Hydropower development: A Boulevard for Prosperious New Nepal. published by Club Fifty: Group of Friends of Activities, Kathmandu,Nepal. souvenir 2065, (2009)37.

[8] Sangroula, D P, Hydropower Development and Its Sustainability with Respect to Sedimentation in Nepal. Insitute of Engineering, 7 (2009)1.

[9] United Nations Sustainable Development, Agenda 21, http://www.un.org/esa/dsd/agenda21/res_agenda21_08.shtml, July 2010.

[10] Upper Tamakoshi Hydropower Limited, http://www.tamakoshihydro.org.np/index.php?option=information\&id=14, April 2011.

[11] Shrestha, MB \& Gurung, B. Introduction and Present Status of Upper Tamakoshi Hydroelectric Project (UTHEP), 2007.

[12] NHA, the Nepal Hydropower Database, http://www.nepal hydro.org.np/nha_db.pdf, November 2010.

[13] Norconsult, Feasibility Study of Upper Tamakoshi Hydroelectric Project Volume 4 A: Main Report, 2005. 